University of Nebraska - Lincoln

DigitalCommons@University of Nebraska - Lincoln

\title{
Identification and characterization of aquaporin-9 (AQP9) in porcine hepatic tissue and hepatocytes in monolayer culture
}

Thomas J. Caperna

USDA-ARS, thomas.caperna@ars.usda.gov

Amy E. Shannon

USDA-ARS, amy.shannon@ars.usda.gov

Mark P. Richards

USDA-ARS

Wesley M. Garrett

USDA-ARS, wesley.garrett@ars.usda.gov

Neil C. Talbot

USDA-ARS

Follow this and additional works at: https://digitalcommons.unl.edu/usdaarsfacpub

Part of the Agricultural Science Commons

Caperna, Thomas J.; Shannon, Amy E.; Richards, Mark P.; Garrett, Wesley M.; and Talbot, Neil C., "Identification and characterization of aquaporin-9 (AQP9) in porcine hepatic tissue and hepatocytes in monolayer culture" (2007). Publications from USDA-ARS / UNL Faculty. 686.

https://digitalcommons.unl.edu/usdaarsfacpub/686

This Article is brought to you for free and open access by the U.S. Department of Agriculture: Agricultural Research Service, Lincoln, Nebraska at DigitalCommons@University of Nebraska - Lincoln. It has been accepted for inclusion in Publications from USDA-ARS / UNL Faculty by an authorized administrator of DigitalCommons@University of Nebraska - Lincoln. 


\title{
Identification and characterization of aquaporin-9 (AQP9) in porcine hepatic tissue and hepatocytes in monolayer culture ${ }^{\text {氶 }}$
}

\author{
Thomas J. Caperna ${ }^{\mathrm{a}, *}$, Amy E. Shannon ${ }^{\mathrm{a}}$, Mark P. Richards ${ }^{\mathrm{a}}$, \\ Wesley M. Garrett ${ }^{a, b}$, Neil C. Talbot ${ }^{a, b}$ \\ ${ }^{a}$ Growth Biology Laboratory, Animal and Natural Resources Institute, USDA/ARS, \\ Beltsville Agricultural Research Center, USDA, Beltsville, MD, United States \\ ${ }^{\mathrm{b}}$ USDA-ARS, ANRI, Biotechnology and Germplasm Lab, United States
}

Received 12 January 2006; received in revised form 24 March 2006; accepted 27 March 2006

\begin{abstract}
Aquaporins (AQPs) are members of a large family of integral membrane proteins involved in the rapid movement of water and neutral solutes across cell membranes. In this study, we have prepared an affinity-purified porcine-specific polyclonal antiserum to AQP9 and have investigated the distribution and expression of AQP9 in pig liver tissue and in hepatocytes in primary culture. Immunocytochemical analysis showed that AQP9 was primarily localized in the membrane structures of hepatocytes and was not associated with intrahepatic bile ducts or blood vessels. Western blot analysis indicated that AQP9 ranged in apparent molecular mass between 27 and $38 \mathrm{kD}$ in whole liver and hepatocyte membrane fractions; minor components were also observed at approximately $34 \mathrm{kD}$ in the cytosol compartment of hepatocytes, bile duct and gall bladder. A prominent immunoreactive band at $44 \mathrm{kD}$ was shown to be an artifact of Western blot analysis. In primary cultures of porcine hepatocytes, glucagon enhanced absolute levels of AQP9 protein, while gene expression was enhanced by T3 and glucagon. Insulin alone had no discernable influence on AQP9 gene expression or its cellular protein levels. These data
\end{abstract}

\footnotetext{
Mention of trade name, proprietary product or vendor does not constitute a guarantee or warranty of the product by the U.S. Department of Agriculture or imply its approval to the exclusion of other products or vendors that also may be suitable.

* Corresponding author at: USDA-ARS, ANRI, Growth Biology Laboratory, Building 200, Room 202, BARCEast, Beltsville, MD 20705, United States. Tel.: +1 301504 8506; fax: +1 3015048623.

E-mail address: caperna@ anri.barc.usda.gov (T.J. Caperna).
} 
suggest that AQP9 is a major AQP in porcine hepatic tissue and appears to be primarily responsive to glucagon induction.

(C) 2006 Elsevier Inc. All rights reserved.

Keywords: Pig hepatocytes; AQP9; Glucagon; Insulin; T3

\section{Introduction}

Aquaporins (AQPs) are members of a large family of integral membrane proteins primarily involved in the regulated movement of water across cell membranes [1,2]. At least 13 AQPs, designated AQP0-AQP12, have been identified in mammalian tissues [3] and a subset (AQP3, -7, -9, and -10) have been designated aquaglyceroporins which transport neutral solutes, including urea and glycerol under physiological conditions $[2,4]$. Following initial observations and cloning experiments, numerous studies have characterized the tissue-specific and intracellular distribution of AQPs in rat and human tissues. Specifically, AQP0, -8 and -9 have been localized in hepatic parenchymal cells [5]. In the liver, these AQPs act in concert with ion transporters and facilitate metabolic activity associated with cell volume perturbations, osmotic balance, concentration and movement of biliary solutes and may be involved in glycogen turnover [5]. The observed coordinated regulation between AQPs in fat and liver via insulin [6] and studies which demonstrated that AQP7 knockout mice were obese [7], have highlighted the role of aquaglyceroporins in energy metabolism. In addition to induction and inhibition of gene expression via hormones, other mechanisms also regulate hepatic AQP activity [5]. For example, AQP8 (but not AQP9 or AQP0) moves from intracellular vesicles to the canalicular membranes following glucagon (cAMP) stimulation, resulting in a rapid movement of intracellular water [8,9]. In the present study, we have developed and characterized a specific antiserum to porcine AQP9 to identify AQP9 in porcine hepatic tissues which also serves as a tool to investigate the role of this molecule in the energy metabolism of porcine hepatocytes.

\section{Materials and methods}

\subsection{Tissue samples}

Care and treatment of all pigs in this study were approved by the Institutional Animal Care and Use Committee of the U.S. Department of Agriculture. Whole livers were obtained from electro-stunned castrate male pigs, rinsed in Tris-saline and frozen at $-80{ }^{\circ} \mathrm{C}$ until used. Cytosol and membrane fractions were prepared by centrifugation and differential solubilization in octylglucoside [10]. Briefly, liver tissue was homogenized and exposed to ultrasound in buffer [ $2 \mathrm{mM}$ octylgucoside, $1 \mathrm{mM}$ diethyldithicarbamate (DEDTC), $10 \mathrm{mM}$ ethylenediamine-tetraacetic acid (EDTA) in $50 \mathrm{mM}$ Tris, $\mathrm{pH}$ 8] and centrifuged at $30,000 \times g$ for $60 \mathrm{~min}$ at $4{ }^{\circ} \mathrm{C}$. The supernatant (cytosol) was harvested and the particulate fraction was solubilized by ultrasound in $20 \mathrm{mM}$ Tris containing $50 \mathrm{mM}$ EDTA, $0.1 \mathrm{mM}$ DEDTC and $32 \mathrm{mM}$ octylglucoside and centrifuged at $16,000 \times g$ for $15 \mathrm{~min}$ at $4{ }^{\circ} \mathrm{C}$. 
All buffers contained standard mammalian protease inhibitor cocktail (P-8340, Sigma, St. Louis, MO). Gall bladders were dissected from fresh livers, cut open to expose the epithelial lining and thoroughly rinsed in Tris-saline. The epithelial lining was scraped from the musculature with a razor blade and frozen at $-80^{\circ} \mathrm{C}$. Extra-hepatic bile duct tissue (cystic duct) was removed and frozen at $-80^{\circ} \mathrm{C}$. Membrane and cytosol fractions from bile duct and gall bladder were prepared as described above. Concentration of protein for all tissue and cell samples was determined by the method of Lowry following precipitation in $7 \%$ TCA and $0.07 \%$ Triton-X 100 [11]. BSA was used as a standard.

\subsection{Hepatocyte isolation}

Crossbred barrows ( $n=4,60 \pm 5 \mathrm{~kg}$ ) were stunned by electric shock and exsanguinated. Livers were immediately excised and the left lateral lobe was removed. Hepatocytes were isolated by a two-step collagenase digestion procedure essentially as previously described $[12,13]$, where only a small portion (approximately $80 \mathrm{~g}$ ) of the lateral lobe was used. Viability of hepatocytes isolated by low speed centrifugation was $84 \pm 1 \%$ by trypan blue dye exclusion.

\subsection{Hepatocyte culture}

Hepatocytes $\left(4.5 \times 10^{6}\right)$ were seeded into T-25 flasks, pre-coated with pig tail collagen and cultured as previously described [13]. Briefly, cells were initially maintained in William's E medium containing insulin-transferrin-selenium (ITS) and 10\% fetal bovine serum (FBS). Following a $3 \mathrm{~h}$ attachment period, flasks were washed with HEPES-buffered saline, and William's E medium containing 5\% FBS and ITS was added to each flask. On the following day, flasks were washed twice and media was replaced with serum-free William's E basal medium containing $10 \mathrm{nM}$ dexamethasone, $100 \mu \mathrm{M}$ (-mercaptoethanol, $10 \mathrm{mM}$ HEPES, $10 \mathrm{nM} \mathrm{Na} 2 \mathrm{SeO}_{3}, 1 \mathrm{mM}$ carnitine, $2 \mathrm{mM}$ glutamine, antibiotics, $0.01 \%$ DMSO, $0.1 \% \mathrm{BSA}$ and $1 \mathrm{ng} / \mathrm{ml}$ bovine insulin. For protein determination studies, hormones were added when serum-free conditions were initiated and maintained for an additional $48 \mathrm{~h}$. For gene expression studies the basal medium ( $1 \mathrm{ng} / \mathrm{ml}$ insulin) was used for an additional day and experimental hormone treatments were added for the final $24 \mathrm{~h}$ period. All media were changed daily and experiments were terminated approximately $72 \mathrm{~h}$ following the initiation of culture. Insulin and glucagon were used at $100 \mathrm{ng} / \mathrm{ml}$ and triiodothyronine (T3) was added at $1 \times 10^{-7} \mathrm{M}$. Except where noted, all media, cell culture and assay reagents were purchased from Sigma. After 3 days of culture, cell monolayers were washed with ice-cold glucose-free HEPES-buffered saline. Cells from each flask were scraped in either $2.5 \mathrm{ml}$ of $0.1 \times$ PBS containing $0.2 \%$ Triton-X 100 and protease inhibitors, or $2.0 \mathrm{ml}$ TRI-Reagent (Invitrogen, Carlsbad, CA), depending on the experiment. All cell material was stored at $-80{ }^{\circ} \mathrm{C}$ prior to analysis.

\subsection{Peptide synthesis and antiserum production}

Peptide synthesis, antiserum production and affinity purification were conducted according to standard and proprietary protocols (Sigma-Genosys Biotechnologies Inc., The 
Woodlands, TX). A peptide corresponding to amino acids 5-18 (MEQKKKSLKQRLVL, based upon partial sequence available in databases) of the porcine AQP9 protein sequence was synthesized, and rabbits were immunized as previously described [14]. The synthetic peptide was used to prepare an affinity column and a portion of the final bleed was used to prepare the affinity-purified antiserum according to proprietary methods (Sigma-Genosys Biotechnology Inc.); the affinity-purified preparation from a single rabbit was used in this study. A control immunoglobulin fraction was prepared from a portion of the preimmunization serum (from the same rabbit) which was precipitated with $33 \%$ ammonium sulfate (three times), and subjected to Mono-Q ion exchange chromatography (FPLC, GE Healthcare, Piscataway, $\mathrm{NJ}$ ) in $20 \mathrm{mM}$ piperazine buffer ( $\mathrm{pH} 9.5)$ using a $0-0.4 \mathrm{M} \mathrm{NaCl}$ gradient. Protein concentration was determined as described above, and all IgG fractions were stored at $-80^{\circ} \mathrm{C}$.

\subsection{Western blot analysis}

Cultured hepatocyte material and tissue samples were homogenized by sonic disruption prior to final solubilization in concentrated gel loading buffer. For quantitative analyses following in vitro incubations, $25 \mu \mathrm{g}$ protein from individual flasks was loaded onto each lane of $12 \%$ polyacrylamide gels $(7 \mathrm{~cm} \times 8 \mathrm{~cm} \times 0.15 \mathrm{~cm}$, Mini Protein II system, Bio-Rad, Hercules, CA) and SDS gel electrophoresis was carried out according to the Laemmli method under reducing conditions [15]. All samples were boiled for $5 \mathrm{~min}$ and centrifuged before loading. Separated proteins were transferred from gels to PVDF membranes (ImmobilonP, Millipore Corp., Bedford, MA) using a semi-dry electro-blotting system (Bio-Rad) for $1.5 \mathrm{~h}$ at $16-25 \mathrm{~V}$ in a Tris-glycine blotting buffer containing $20 \%$ methanol. Blots were rinsed and stained for total protein with Coomassie Brilliant Blue, then dried and imaged by laser densitometry (PDSI, GE Healthcare). Dried blots were wetted with methanol, incubated with Tris-buffered saline (TBS, pH 7.5) and blocked overnight at $4{ }^{\circ} \mathrm{C}$ in buffer containing 5\% dried skim milk and 0.1\% Tween-20 (Surfact-Amps 20, Pierce, Rockford, IL). The blots were then incubated with affinity-purified anti-porcine AQP9 $(0.3 \mu \mathrm{g} / \mathrm{ml}$ in TBS containing $1 \%$ dried skim milk and $0.1 \%$ Tween-20), washed with the same buffer and further incubated with HRP-conjugated donkey anti-rabbit IgG (1:10,000 dilution, NA9340V, GE Healthcare). Blots were developed with ECL plus reagent (GE Healthcare) according to the manufacturer's recommendations, visualized by fluorescence densitometry (Typhoon, GE Healthcare), and band intensity was quantified using ImageQuant Software.

\subsection{Immuno-capture}

Antibody-mediated capture of proteins from whole liver membranes was performed with the Seize ${ }^{\circledR}$ Protein A/G-coated plate immunoprecipitation system (Kit \# 45350, Pierce). Wells were pre-incubated with optimal amounts $(0.5 \mu \mathrm{g})$ of affinity-purified anti-porcine AQP9 or $0.5 \mu \mathrm{g}$ pre-immune IgG. Additional control wells without IgG or membrane protein were also included, and immuno-capture was carried out using the manufacturer's recommended buffers and procedure except that a single extraction was performed using $60 \mu \mathrm{l} 1 \times \mathrm{SDS}$ loading buffer at $60^{\circ} \mathrm{C}$ for $30 \mathrm{~min}$. Use of incubation 
buffers not containing detergents resulted in a total lack of AQP9 binding activity. Proteins were separated by SDS gel electrophoresis, transferred to PVDF membranes and Western blot using affinity-purified anti-porcine AQP9 was performed as described above.

\subsection{Immunohistochemistry}

Pig liver tissue was freshly obtained from an adult male pig, immersed in Tissue-Tek OCT compound (Miles Inc., Elkhart, IN) in Peel-A-Way disposable embedding molds (Polysciences Inc., Warrington, PA) and frozen in a dry ice ethanol bath. Frozen sections were cut at a thickness of $5 \mu \mathrm{m}$ on a Hacker-Bright cryostat (Hacker Instruments Inc., Fairfield, NJ) and thaw mounted onto Superfrost Plus microscope slides (Fisher Scientific, Pittsburgh, PA).

The procedure used for immunostaining frozen sections was essentially as previously described [16] except that in the present study tissue sections were fixed in $10 \%$ neutral buffered formalin, and detection of primary antibodies was accomplished by immunofluorescence. Anti-porcine AQP9 antibody was used at a concentration of $1 \mu \mathrm{g} / \mathrm{ml}$. The purified pre-immune $\mathrm{IgG}$ fraction was used at a concentration of $1 \mu \mathrm{g} / \mathrm{ml}$ for a negative control. The rabbit primary antibody was detected with Alexa fluor 488 goat anti-rabbit IgG (Molecular Probes, Eugene, OR) at a dilution of 1:400. Visualization of the actin cytoskeleton was accomplished with Alexa fluor 594 phalloidin (Molecular Probes, Eugene, OR) at $2 \mathrm{U} / \mathrm{ml}$ $(66 \mathrm{nM})$, and the specimens were mounted in Prolong Gold (Molecular Probes, Eugene, OR). Images were acquired in in-frame mode with a Zeiss LSM 410 confocal microscope (Carl Zeiss, Thornwood, NY) through a 40X C-apochromat 1.2 NA water immersion objective. The 488 and $568 \mathrm{~nm}$ lines of an Omnichrome Ar/Kr laser (Omnichrome Corp., Chino, CA) were used to excite Alexa fluor 488 and 594, respectively. A band-pass 515-540 nm filter was used for the green emitting Alexa fluor 488, and a long-pass $590 \mathrm{~nm}$ filter for the red emitting Alexa fluor 594. Individual optical sections were digitally recombined into a single composite image using LSM software (Carl Zeiss Inc.).

\subsection{Reverse transcription polymerase chain reaction (RT-PCR)}

Total RNA was isolated from hepatocytes using the TRI-Reagent (Invitrogen) and AQP9 gene expression was determined using a relative quantitative technique described previously [17]. Reverse transcription (RT) reactions $(20 \mu \mathrm{l})$ were performed with $1 \mu \mathrm{g}$ total RNA. Polymerase chain reaction (PCR) was performed in $25 \mu$ l containing 10 pmol each of AQP9 specific primers (see below) and 5 pmol each of a primer/competimer mixture (3:7) specific for $18 \mathrm{~S}$ rRNA (Universal 18S kit, Ambion Inc., Austin, TX). Thermal cycling parameters were: 1 cycle $94^{\circ} \mathrm{C}$ for $2 \mathrm{~min}$, followed by 35 cycles of: $94{ }^{\circ} \mathrm{C}$ for $30 \mathrm{~s}, 58^{\circ} \mathrm{C}$ for $30 \mathrm{~s}, 72^{\circ} \mathrm{C}$ for $1 \mathrm{~min}$ with a final extension at $72{ }^{\circ} \mathrm{C}$ for $8 \mathrm{~min}$. The following primers were used:

AQP9 (496 bp product):

- Sense: 5'-GGATTTTCAATGGCAGTTGG-3';

- Antisense: 5'-CGGTGAAAAGTCTGGGACTC-3'.

The identity of the PCR amplicon (496 bp) as a fragment of the porcine AQP9 gene was confirmed by subjecting purified AQP9 PCR products to direct bi-directional automated 
fluorescent DNA sequencing utilizing a Beckman Coulter CEQ 8000XL Genetic Analysis System with a dye terminator cycle sequencing kit (Beckman Coulter Inc., Fullerton, CA).

\subsection{Capillary electrophoresis-laser induced fluorescence (CE-LIF)}

Aliquots $(2 \mu \mathrm{l})$ of RT-PCR samples were diluted 1:100 with $\mathrm{dH}_{2} \mathrm{O}$ prior to CE-LIF. A P/ACE MDQ (Beckman Coulter Inc.) equipped with an argon ion LIF detector was used. Capillaries were $75 \mu \mathrm{m} \mathrm{ID} \times 32 \mathrm{~cm} \mu$ SIL-DNA (Agilent Technologies, Palo Alto, CA). EnhanCE dye (Beckman Coulter Inc.) was added to the DNA separation buffer (Sigma) to a final concentration of $0.5 \mu \mathrm{g}$. Samples were loaded by electrokinetic injection at $3.5 \mathrm{kV}$ for $5 \mathrm{~s}$ and run in reverse polarity at $8.1 \mathrm{kV}$ for $5 \mathrm{~min}$. P/ACE MDQ software (Beckman Coulter Inc.) was used to calculate peak areas for the PCR products separated by $\mathrm{CE}$. The level of gene expression was determined as the ratio of integrated peak area for each individual gene PCR product relative to that of the co-amplified 18S rRNA internal standard.

\subsection{Statistical analysis}

To evaluate the effects of hormone treatment on the levels of AQP9 in hepatocyte cultures, quantitative results obtained from fluorescence evaluation of individual bands from Western blot experiments were analyzed by GLM ANOVA. When significant treatment effects were observed, individual means were separated by Bonferroni multiple range comparison test, where significance was set at $P<0.05$ (Number Cruncher Statistical Systems, Kayesville, UT).

\section{Results}

Immunocytochemical staining of frozen liver sections with affinity-purified anti-AQP9 antiserum revealed intense and even antibody-antigen reactions throughout the hepatic parenchyma with heavy concentration of staining on membrane surfaces of hepatocytes (Fig. 1A). There was no apparent binding of the anti-AQP9 antibody within bile ducts or portal regions. Incubation of tissues with pre-immune purified IgG showed no specific staining (Fig. 1B).

Western blot analysis of membrane and cytosol fractions from freshly isolated hepatocytes, liver, gall bladder, and bile duct are shown in Fig. 2A. In hepatocyte and whole liver membranes (lanes 1 and 3), the distribution of anti-AQP9 reactive proteins revealed a series of bands in the $27-38 \mathrm{kD}$ range. An additional band at $44 \mathrm{kD}$ was also observed, however this band is believed to be an artifact of the Western blotting procedure (see below). The cytosol fractions (lanes 2 and 4) contained markedly less AQP9 than membranes and the main reactive protein appeared at approximately $34 \mathrm{kD}$. The $44 \mathrm{kD}$ band was more prominent in cytosol fractions than in membrane preparations. The gall bladder and bile duct membranes (lanes 5 and 7) showed no reaction with the antibody while the cytosol fractions (lanes 6 and 8) showed a $34 \mathrm{kD}$ band with an additional $38 \mathrm{kD}$ band observed in the gall bladder. Incubation of blots with purified pre-immune IgG from the same rabbit 

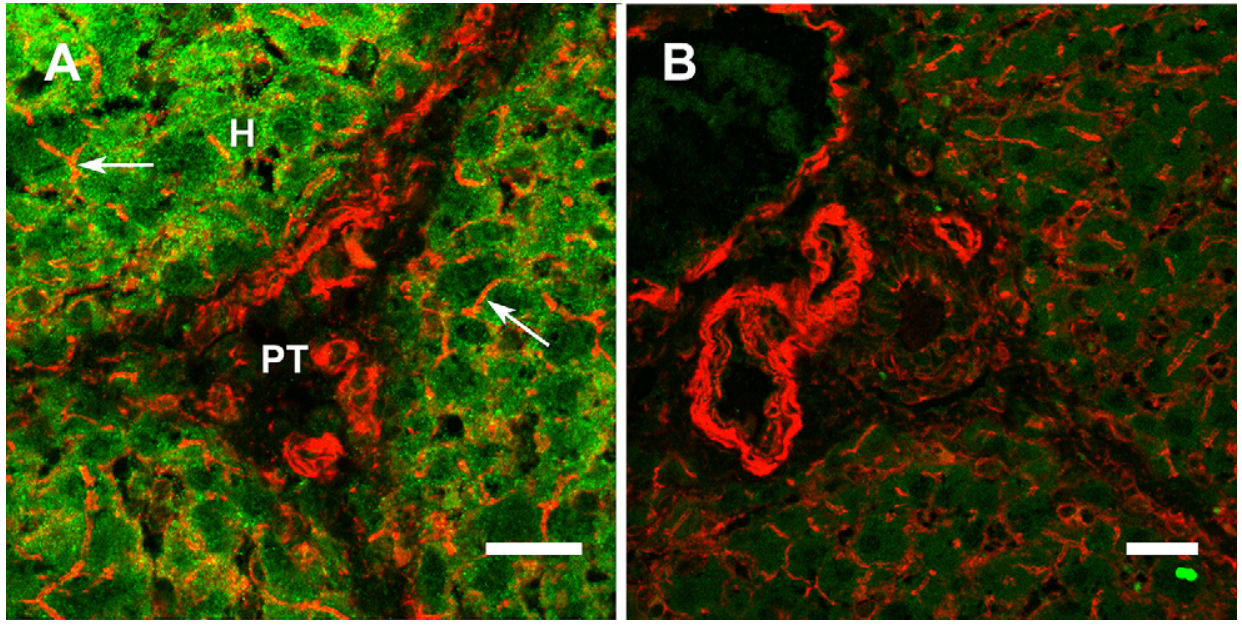

Fig. 1. Double-stained immunohistochemical analysis of adult pig liver frozen sections with porcine-specific anti-AQP9 antibody. (A) Portal triad (PT) area showing extensive staining of AQP9 (green) in hepatocyte (H) membrane regions and no staining in bile ductular or venous structures. Red staining depicts phalloidin-labeled actin cytoskeletal elements (canaliculi, arrow heads). (B) A similarly-stained section showing large central vein but incubated with pre-immune control IgG. Scale bars represent $25 \mu \mathrm{m}$.

revealed very little binding when incubated and developed under the same conditions (Fig. 2B). Blocking of specific binding was observed when the peptide used to immunize the rabbit was pre-incubated with the affinity-purified porcine AQP9 antiserum (Fig. 3), which indicated that all apparent binding was due to IgG molecules with specificity for the immunizing peptide.

Further characterization of binding through solid phase immunoprecipitation (Fig. 4) indicated that in liver cell membranes, the majority of AQP9 $(27-38 \mathrm{kD})$ was bound and eluted from the immuno-affinity matrix (lane 4). In contrast, the $44 \mathrm{kD}$ immunoreactive protein did not bind to the antibody coated matrix, was not detected upon Western blotting

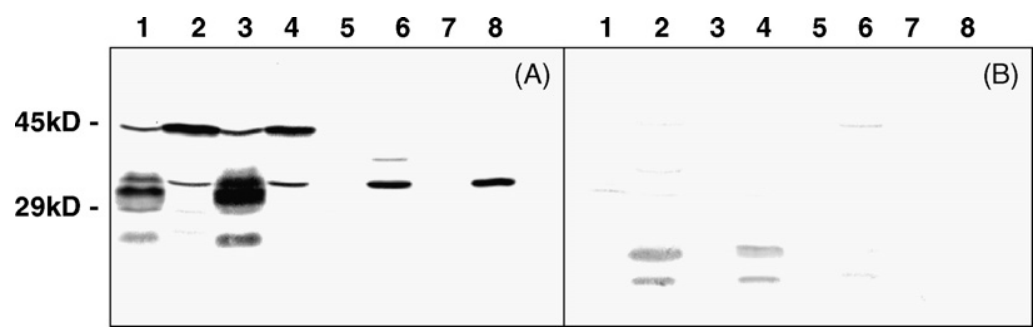

Fig. 2. Western blot analysis of pig liver tissues incubated with affinity-purified anti-porcine AQP9. Equivalent amounts of protein $(25 \mu \mathrm{g})$ were electrophoresed, blotted onto PVDF membranes and incubated with either $0.3 \mu \mathrm{g} / \mathrm{ml}$ affinity-purified AQP9 antiserum (A) or with $0.3 \mu \mathrm{g} / \mathrm{ml}$ pre-immune control IgG (B). Protein preparations were as follows: lane 1, hepatocyte membranes; lane 2, hepatocyte cytosol; lane 3, liver membranes; lane 4, liver cytosol; lane 5, gall bladder membranes; lane 6, gall bladder cytosol; lane 7, bile duct membranes; lane 8 , bile duct cytosol. 


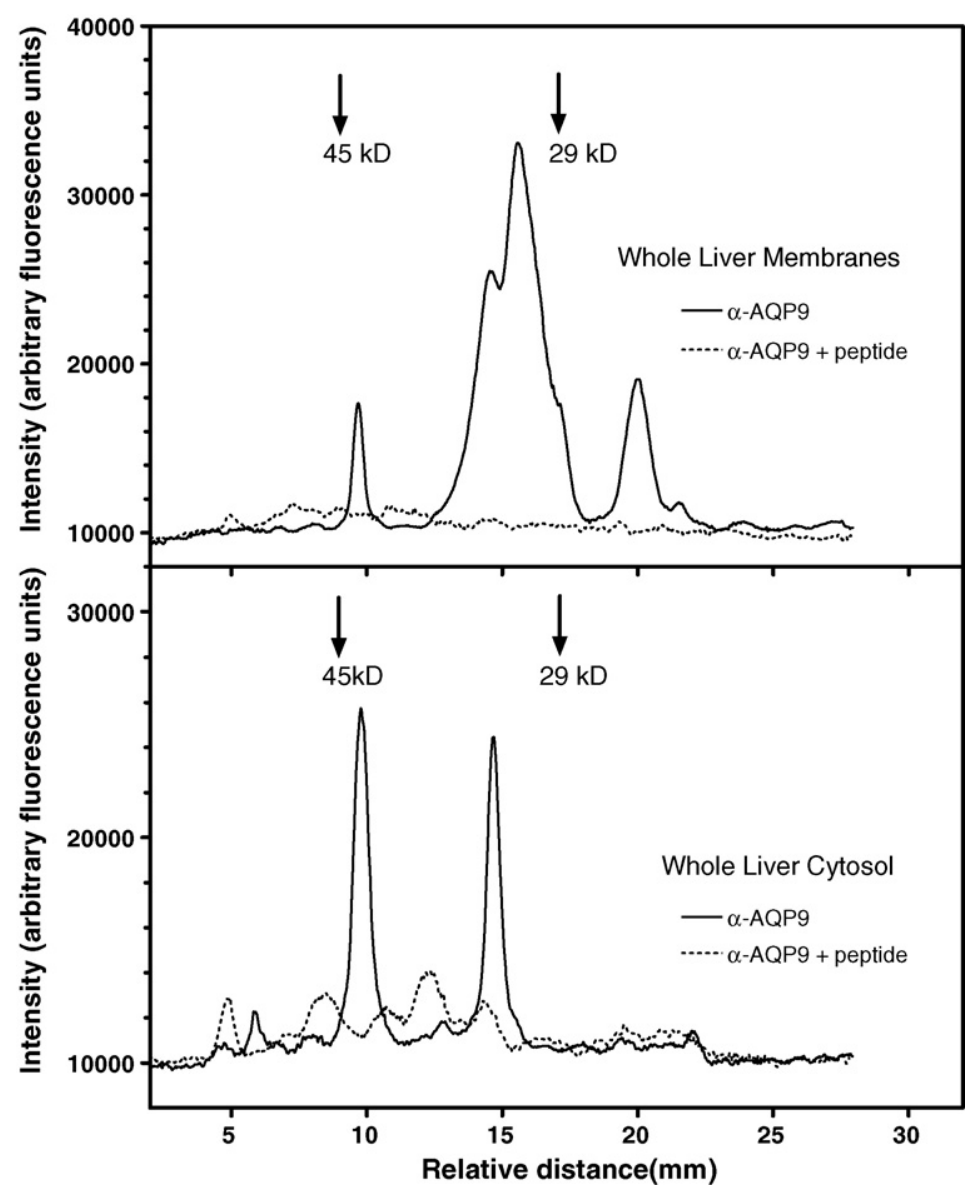

Fig. 3. Densitometry of porcine AQP9 Western blot of whole liver tissue following removal of specific IgGs by incubation with peptide antigen. Samples of whole liver membranes (top panel) and cytosol (bottom panel) were electrophoresed, blotted onto PVDF membranes and probed with anti-AQP9 antiserum (control) or antiserum previously incubated with excess immunizing peptide. To prepare the antibody solutions an aliquot of antiserum $(1.6 \mu \mathrm{g})$ was mixed overnight $\left(4^{\circ} \mathrm{C}\right)$ in phosphate buffered saline in the presence of $50 \mu \mathrm{g}$ immunizing peptide. Immune complexes were centrifuged and the remaining supernatant buffer was diluted five-fold in primary antibody incubation buffer and incubated with PVDF membranes. For the control blot, a similar aliquot of antiserum was handled identically except without the peptide addition. Western blots were developed as described above and the lane traces were obtained using ImageQuant Software.

of the eluted material and only appeared with the material that did not bind to either control or hyperimmune $\operatorname{IgG}$ (lanes 8 and 9). This observation could indicate that the $44 \mathrm{kD}$ binding occurs at a site remote from the antigen binding site but is present on IgG molecules induced by immunization. Alternatively, the $44 \mathrm{kD}$ protein could contain a cryptic antigenic determinant with sequence homology to the immunizing peptide which is unmasked during denaturation and only observed following electrophoresis and attachment to the PVDF membrane matrix. 


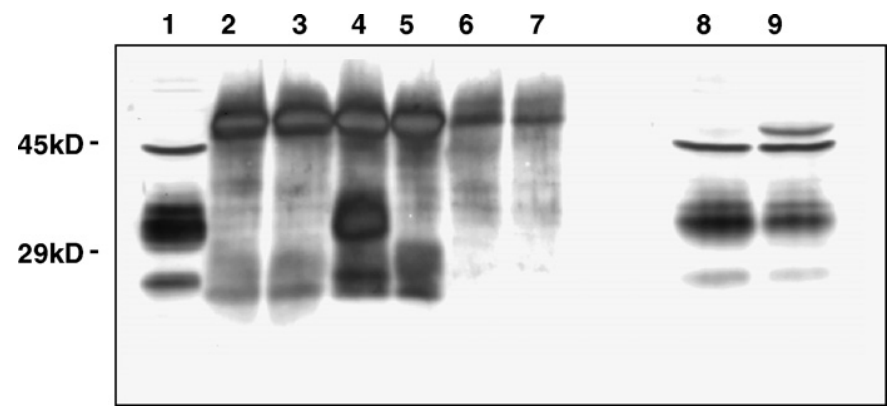

Fig. 4. Immunoprecipitation of AQP9 from whole liver membrane proteins. Protein preparations and incubations were as follows: lane 1, $25 \mu \mathrm{g}$ protein, non-extracted membrane protein; lane 2, extract from control IgG-coated well with $50 \mu \mathrm{g}$ membrane protein; lane 3, control IgG-coated well with no membrane protein added; lane 4, anti-AQP9-coated well with $50 \mu \mathrm{g}$ membrane protein; lane 5, anti-AQP9-coated well with no membrane protein added; lane 6 , control well with no IgG but with $50 \mu \mathrm{g}$ membrane protein; lane 7, control well without IgG and no added membrane protein; lane 8 represents the protein that did not initially bind to control IgG (viz., the first wash from the well that contained lane 2 material); lane 9 represents the protein that did not initially bind to anti-AQP9 (lane 4 material). Western blot analysis was performed using the anti-AQP9 antiserum as the primary antibody. Note that in lanes $2-9$, only approximately $60 \%$ of the extracted material was loaded onto each lane of the SDS gel.

To investigate the effects of hormones on AQP9 levels in porcine hepatocytes, monolayer cultures were incubated for $48 \mathrm{~h}$ in the presence of low insulin (basal conditions, $1 \mathrm{ng} / \mathrm{ml}$ ), and high insulin or glucagon at $100 \mathrm{ng} / \mathrm{ml}$, with or without $\mathrm{T} 3\left(10^{-7} \mathrm{M}\right)$ in the serum-free medium. In cultured hepatocytes the molecular distribution of AQP9 was similar to that observed in freshly prepared hepatocytes and whole liver with specific prominent bands at 34 and $38 \mathrm{kD}$ (Fig. 5). Overall intensity of immunoreactivity, is indicative of the whole cell preparation which contains a mixture of cytosol and membrane components. The intensity of each band or series of bands was analyzed by fluorescence densitometry in duplicate cultures from four independent experiments (Fig. 6). The $44 \mathrm{kD}$ band was similar across all treatment

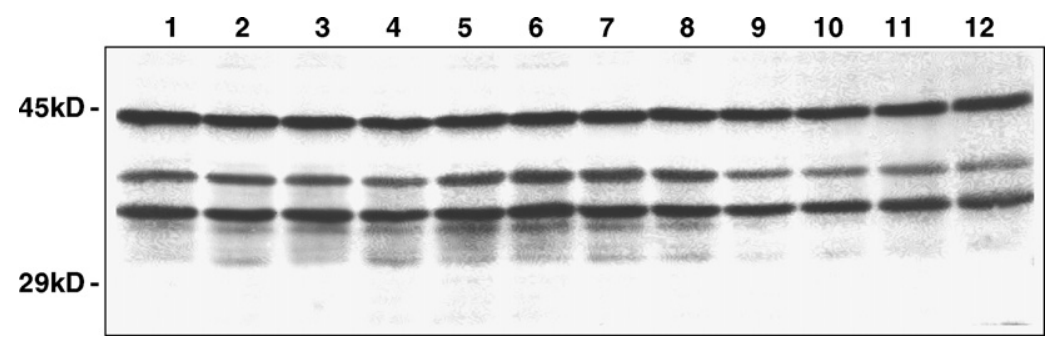

Fig. 5. Western blot analysis of AQP9 from duplicate cultures from one experiment with porcine hepatocytes. Following 48 h of incubation under various conditions, hepatocyte monolayers were washed, scraped, homogenized and $25 \mu \mathrm{g}$ total cell protein from each flask was electrophoresed and analyzed by Western blot with anti-porcine AQP9 antiserum as primary antibody. Protein preparations were from the following conditions: lanes 1 and 2, control ( $1 \mathrm{ng} / \mathrm{ml}$ insulin); lanes 3 and 4 , control $+10^{-7} \mathrm{M} \mathrm{T} 3$; lanes 5 and $6,100 \mathrm{ng} / \mathrm{ml}$ glucagon; lanes 7 and 8 , $100 \mathrm{ng} / \mathrm{ml}$ glucagon $+10^{-7} \mathrm{M} \mathrm{T} 3$; lanes 9 and $10,100 \mathrm{ng} / \mathrm{ml}$ insulin; lanes 11 and $12,100 \mathrm{ng} / \mathrm{ml}$ insulin $+10^{-7} \mathrm{M}$ T3. 

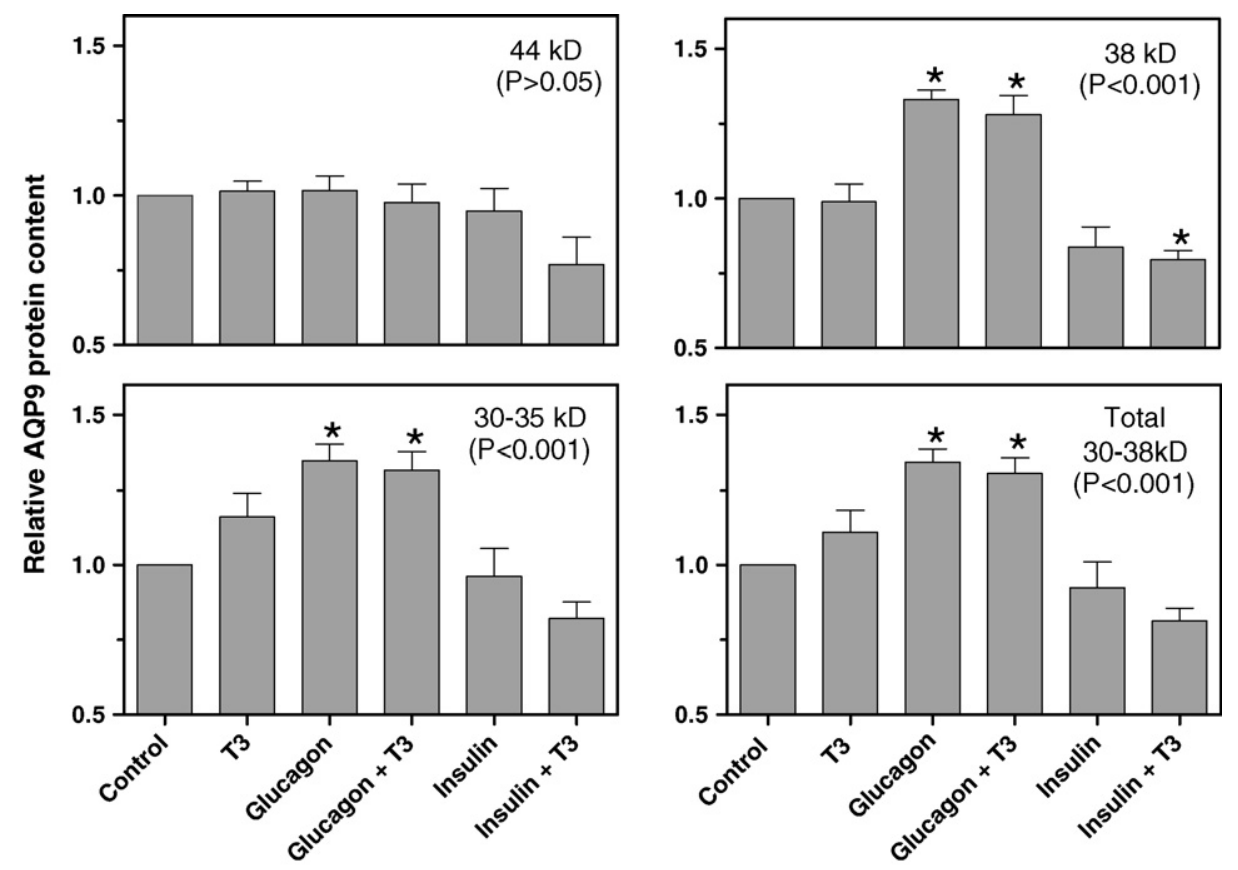

Fig. 6. Quantitative analysis of AQP9 in cultured hepatocytes from four experiments. Four experiments were conducted and samples were subjected to Western blot as described in Fig. 5. Anti-AQP9 reactive proteins were quantified by fluorescence scans which were analyzed by ImageQuant Software where the intensity of all observable bands between 30 and $50 \mathrm{kD}$ was determined and compared to the average of the control cultures on each gel. Accordingly, three specific binding regions were separated; $44 \mathrm{kD}$ band, $38 \mathrm{kD}$ band and the region encompassing several bands between 30 and $35 \mathrm{kD}$. The relative values from separate experiments were compared by GLM ANOVA and the significance values are indicated in the panels for each protein band or region. Values are means \pm S.E.M. $(n=4)$ and means significantly different from respective controls $(P<0.05)$ are marked with an asterisk (*).

groups $(P>0.05$, ANOVA), whereas significant differences $(P<0.001)$ among treatments were observed for the lower molecular weight species. The concentration of AQP9 (38 kD band) was increased by $33 \%(P<0.05)$ in cells treated with $100 \mathrm{ng} / \mathrm{ml}$ glucagon and $28 \%$ when treated with glucagon and T3. In contrast, $38 \mathrm{kD}$ band was reduced by $20 \%(P<0.05)$ in cells incubated with $100 \mathrm{ng} / \mathrm{ml}$ insulin and T3. Similarly, when the multiple bands in the range of 30-35 kD were quantified, glucagon and glucagon/T3-treated cells were increased by 35 and $32 \%$, respectively $(P<0.05)$. When all the AQP9 regions were added together (total AQP9, 30-38 kD), glucagon and glucagon/T3 were associated with an overall 34 and $31 \%(P<0.05)$ increase, respectively, in AQP9 concentration. Other hormones involved in energy metabolism including leptin, ghrelin and GLP-1 were added at $100 \mathrm{ng} / \mathrm{ml}$ for $48 \mathrm{~h}$ but were not associated with altered AQP9 expression (data not shown).

A final experiment (triplicate flasks/condition from each of two pigs) was conducted to evaluate whether increased AQP9 protein content was associated with altered gene expression (Fig. 7). In hepatocytes cultured for the final $24 \mathrm{~h}$ under the same conditions that AQP9 


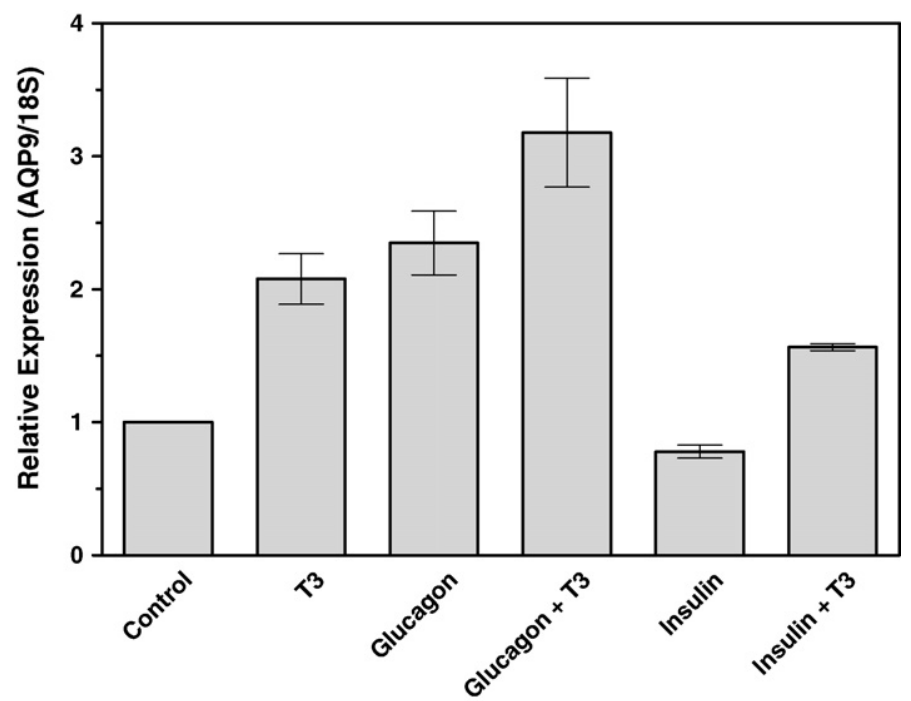

Fig. 7. Expression of the AQP9 gene determined by relative quantitative RT-PCR in cultured hepatocytes following $24 \mathrm{~h}$ incubation with insulin, glucagon and triiodothyronine (T3). Relative expression values represent the average of AQP9/18S ratios from two separate experiments each with triplicate flasks that were normalized to the control culture values from each experiment. Error bars represent the values obtained from each experiment; statistical analyses were not performed.

protein was evaluated, glucagon and T3 additions were associated with a marked increase in AQP9 mRNA content. In addition, insulin attenuated the T3 enhancement of AQP9 mRNA (Fig. 7).

\section{Discussion}

In this study we have developed and characterized an affinity-purified rabbit polyclonal antiserum to porcine $\mathrm{AQP} 9$, which was shown to be a major $\mathrm{AQP}$ in hepatocyte membranes; AQP9 was not detected in gall bladder or bile duct membranes. Immunoreactivity in porcine hepatic tissue, was detected in the range of $27-38 \mathrm{kD}$ and primarily localized within hepatocyte membranes. This distribution pattern is consistent with observations in rat liver where membrane preparations showed a multiple banding pattern of AQP9 immunostaining between at 30 and $35 \mathrm{kD}$ [18], although, a single immunoreactive band at $28 \mathrm{kD}$ [19] or $33 \mathrm{kD}$ [20] has also been described. Additionally, Nicchia and coworkers showed Western blot analysis of purified hepatic membrane preparation with immunoreactivity in the $43-44 \mathrm{kD}$ range, although this was not addressed or discussed by the authors [18]. Multiple, molecular weight forms of AQP9 are usually attributed to glycosylation [21], but at least one study has indicated that $\mathrm{AQP9}$ in rat liver membranes was not glycosylated [18]. While in the present study low concentrations of AQP9 were observed in the hepatocytes cytosol fraction, contamination from membrane components cannot be ruled out. 
Immunoprecipitation (immuno-capture) was used to further characterize the apparent immunoreactive $44 \mathrm{kD}$ protein present in the membrane fraction. The $44 \mathrm{kD}$ protein did not bind to the IgG which was previously bound to the protein $\mathrm{A} / \mathrm{G}$ binding domain, initially suggesting that binding of the $44 \mathrm{kD}$ protein may be located within Fc region of the IgG molecule. Alternatively, the native form of the $44 \mathrm{kD}$ protein (which would be present in immuno-capture and immunocytochemistry experiments) could contain a buried cross-reactive antigenic determinant which is only exposed following denaturation and electrophoresis. When the antigen-specific hyperimmune $\mathrm{IgG}$ molecules were removed by pre-incubating the antiserum with purified peptide antigen, the $44 \mathrm{kD}$ binding activity observed on Western blots was also eliminated, indicating that $44 \mathrm{kD}$ protein was indeed binding the same IgG molecules that were binding to AQP9. Taken together, these observations indicate that the $44 \mathrm{kD}$ molecule is probably not AQP9 but represents either a spurious antigenic cross-reactivity or an IgG binding protein with affinity to a specific peptide sequence or carbohydrate structure present in the hyperimmune IgGs. Finally, the expression of the $44 \mathrm{kD}$ protein was not regulated by insulin, glucagon or T3 and since the $44 \mathrm{kD}$ protein is primarily associated with the cytosol it is highly unlikely to be AQP9.

In a previous study, using a commercial antiserum to rat AQP9, we observed specific, but minimal staining of hepatic parenchymal cells by Western blot and immunocytochemical staining [22]. Moreover, we observed very intense staining of bile duct tissue which appeared to be due to the high level of an immunoreactive molecule that was observed in bile duct membrane tissue and was also approximately $44 \mathrm{kD}$. These observations led to the hypothesis that the distribution of AQP9 in hepatic tissue was different in the pig compared to the rat [22]. In contrast, using the porcine-specific antiserum developed for this study, we now demonstrate that the distribution of AQP9 in the pig liver appears to be similar to its distribution to the rat liver [18-20]. These data serve to underscore the importance of using species-specific immunological reagents even for proteins with high sequence homology. Further, in cases where human and rodent reagents are used to evaluate homologous proteins in domestic species, rigorous evaluation of binding specificity and cross-reactivity is essential.

In this study, it was demonstrated that glucagon raises AQP9 mRNA expression and AQP9 protein in cultured porcine hepatocytes. In contrast, in the presence of insulin and T3, AQP9 tended to be decreased. While T3 alone stimulated expression of AQP9 mRNA, there appeared to be no coordinate induction of protein synthesis or accumulation as a consequence of T3 stimulation. Lack of correlation between protein levels and gene expression has been well documented in several systems [23-25] and recently it has been shown that while bile duct ligation depressed the levels of AQP8 in rat liver, gene expression was actually enhanced [26]. These data suggest that analysis of changes in mRNA levels does not necessarily reflect or predict changes in AQP protein levels or how cell function might be altered.

Previous studies have indicated that AQP9 was under the control of steroid hormones in rat epididymal cells [21], and by cAMP in cultured rat astrocytes [27], but this is the first report that glucagon effected AQP9 expression, presumably through its activation of adenyl cyclases, in hepatic tissue. Coordinated regulation of hepatic AQP9 and adipose AQP7 as a mechanism to shuttle glycerol to hepatocytes from fat depots for glucose production has been proposed [6]. In those studies, insulin inhibited AQP9 expression in H4IIE hepatoma cells 
and in normal but not in diabetic mice [6]. It has also been reported that hepatic AQP9 protein levels were reduced by insulin in vivo and enhanced in STZ-diabetic rats and starved rats, whereas AQP9 was not affected by glucagon or glucocorticoids [28]. In our hands, cultured porcine hepatocytes are exquisitely sensitive to both glucagon and insulin [13,29]. Glucagon markedly enhances urea production (TJC, personal observation) and also enhances ketone secretion and glycogenolysis in porcine hepatocyte cultures [13,29]. Modulation of AQP9 synthesis by glucagon, which may facilitate hepatic transport of urea and glycerol and possibly other gluconegenic precursors, underscores the potential importance of AQPs in the regulation of hepatic energy metabolism. Further studies will be required to elucidate the mechanisms of glucagon control of AQP9 gene expression and whether enhanced AQP9 levels are indeed involved in the transport of glycerol, urea and other solutes in pigs.

\section{Acknowledgements}

Dr. J.P. McMurtry is thanked for critical review of the manuscript and Mr. Steven Poch is thanked for assistance in RNA isolation and RT-PCR analysis. Tom Clover, Janile Tapscott, James Woods and Jim Piatt are thanked for assistance in maintaining and handling experimental animals.

\section{References}

[1] Borgnia M, Nielson S, Engel A, Agre P. Cellular and molecular biology of the aquaporin water channels. Annu Rev Biochem 1999;68:425-58.

[2] Agre P, Kozono D. Aquaporin water channels: molecular mechanisms for human diseases. FEBS Lett 2003;555:72-8.

[3] Castle NA. Aquaporins as targets for drug discovery. Drug Discov Today 2005; 10:485-93.

[4] Tsukaguchi H, Shayakul C, Berger UV, Mackenzie B, Devidas S, Guggino WB, et al. Molecular characterization of a broad selectivity neutral solute channel. J Biol Chem 1998;273:24737-43.

[5] Marinelli RA, Gradilone SA, Carreras FI, Calamita G, Lehmann GL. Liver aquaporins: significance in canalicular and ductal bile formation. Ann Hepatol 2004;3:130-6.

[6] Kuriyama H, Shimomura I, Kishida K, Kondo H, Furuyama N, Nishizawa H, et al. Coordinated regulation of fat-specific and liver-specific glycerol channels, aquaporin adipose and aquaporin 9. Diabetes 2002;51:2915-21.

[7] Hibuse T, Maeda N, Funahashi T, Yamamoto K, Nagasawa A, Mizunoya W, et al. Aquaporin 7 deficiency is associated with development of obesity through activation of adipose glycerol kinase. Proc Natl Acad Sci 2005;102:10993-8.

[8] Huebert RC, Splinter PL, Garcia F, Marinelli RA, LaRusso NF. Expression and localization of aquaporin water channels in rat hepatocytes. J Biol Chem 2002;277:22710-7.

[9] Gradilone SA, Garcia F, Huebert RC, Tietz PS, Larocca MC, Kierbel A, et al. Glucagon induces the plasma membrane insertion of functional aquaporin- 8 water channels in isolated rat hepatocytes. Hepatology 2003;37:1435-41.

[10] Ruiz-Cortés ZT, Men T, Palin M-F, Downey BR, Lacroix DA, Murphy BD. Porcine leptin receptor: molecular structure and expression in the ovary. Mol Reprod Dev 2000;56:465-74.

[11] Nerurkar LS, Marino PA, Adams DO. Quantification of selected intracellular and secreted hydrolases of macrophages. In: Herscowitz HB, Holden HT, Bellanti JA, Ghaffer A, editors. Manual of macrophage methodology. Marcel Dekker Inc.; 1981. p. 229-47.

[12] Caperna TJ, Failla ML, Kornegay ET, Richards MP, Steele NC. Isolation and culture of parenchymal and nonparenchymal cells from neonatal swine liver. J Anim Sci 1985;61:1576-86. 
[13] Fernández-Fígares I, Shannon AE, Wray-Cahen D, Caperna TJ. The role of insulin, glucagon, dexamethasone, and leptin in the regulation of ketogenesis and glycogen storage in primary cultures of porcine hepatocytes prepared from $60 \mathrm{~kg}$ pigs. Domest Anim Endocrinol 2004;27:125-40.

[14] Richards MP, Caperna TJ, Elsasser TH, Ashwell CM, McMurtry JP. Design and application of a polyclonal peptide antiserum for the universal detection of leptin protein. J Biochem Biophys Methods 2000;45:147-56.

[15] Laemmli UK. Cleavage of structural proteins during the assembly of the head of bacteriophage T4. Nature 1970;227:680-5.

[16] Garrett WM, Guthrie HD. Expression of androgen receptors and steroidogenic enzymes in relation to follicular growth and atresia following ovulation in pigs. Biol Reprod 1996;55:949-55.

[17] Richards MP, Poch SM. Quantitative analysis of gene expression by reverse transcription polymerase chain reaction and capillary electrophoresis with laser-induced fluorescence detection. Mol Biotechnol 2002;21:19-37.

[18] Nicchia GP, Frigeri A, Nico B, Ribatti D, Svelto M. Tissue distribution and membrane localization of aquaporin-9 water channel: evidence for sex-linked differences in liver. J Histochem Cytochem 2001;49:1547-56.

[19] Elkjær M-L, Vajda Z, Nejsum LN, Kwon TH, Jensen UB, Amiry-Moghaddam M, et al. Immunolocalization of AQP9 in liver, epididymis, testis, spleen, and brain. Biochem Biophys Res Commun 2000;276:1118-28.

[20] Nihei K, Koyama Y, Tani T, Yaoita E, Ohshiro K, Adhikary LP, et al. Immunolocalization of aquaporin-9 in rat hepatocytes and leydig cells. Arc Histol Cytol 2001;64:81-8.

[21] Pastor-Solar N, Isnard-Bagnis C, Herak-Kramberger C, Sabolic I, Van Hoek A, Brown D, et al. Expression of aquaporin 9 in the adult rat epididymal epithelium is modulated by androgens. Biol Reprod 2002;66:1716-22.

[22] Talbot NC, Garrett WG, Caperna TJ. Analysis of the expression of aquaporin-1 and aquaporin-9 in pig liver tissue: comparison with rat liver tissue. Cells Tissues Organs 2003;174:117-28.

[23] Gygi SP, Rochon Y, Franza BR, Aebersold R. Correlation between protein and mRNA abundance in yeast. Mol Cell Biol 1999;19:1720-30.

[24] Bartling B, Hofmann H-S, Boettger T, Hansen G, Burdach S, Silber R-E, et al. Comparative application of antibody and gene array for expression profiling in human squamous cell lung carcinoma. Lung Cancer 2005;49:145-54.

[25] Rodriguez-Melendez R, Griffin JB, Sarath G, Zempleni J. High-throughput immunoblotting identifies biotindependent signaling proteins in HepG2 hepatocarcinoma cells. J Nutr 2005;135:1659-66.

[26] Carreras FI, Gradilone SA, Mazzone A, García F, Huang BQ, Ochoa JE, et al. Rat hepatocyte aquaporin-8 water channels are down-regulated in extrahepatic cholestasis. Hepatology 2003;37:1026-33.

[27] Yamamoto N, Sobue K, Fujita M, Katsuya H, Asai K. Differential regulation of aquaporin-5 and -9 expression in astrocytes by protein kinase A. Mol Brain Res 2002;104:96-102.

[28] Carbrey JM, Gorelick-Feldman DA, Kozono D, Praetorius J, Nielsen S, Agre P. Aquaglyceroporin AQP9: solute permeation and metabolic control of expression in liver. Proc Natl Acad Sci 2003;100:2945-50.

[29] Caperna TJ, Shannon AE, Poch SM, Garrett WM, Richards MP. Hormonal regulation of leptin receptor expression in primary cultures of porcine hepatocytes. Domest Anim Endocrinol 2005;29:582-92. 